\title{
Biochemical and molecular characterization of adult patients with type I Gaucher disease and carrier frequency analysis of Leu444Pro - a common Gaucher disease mutation in India
}

Jayesh Sheth ${ }^{1 *}$, Dhairya Pancholi ${ }^{1}$, Mehul Mistri ${ }^{1}$, Payal Nath ${ }^{1}$, Chitra Ankleshwaria', Riddhi Bhavsar ${ }^{1}$, Ratna Puri ${ }^{2}$, Shubha Phadke ${ }^{3}$ and Frenny Sheth ${ }^{1}$

\begin{abstract}
Background: Gaucher disease is a rare pan-ethnic disorder which occurs due to an increased accumulation of undegraded glycolipid glucocerebroside inside the cells' lysosomes. A beta-Glucosidase (GBA) gene defect results in glucocerebrosidase enzyme deficiency. Though the disease is mainly diagnosed in childhood, the adult manifestation is often missed or identified late due to the failure to recognize the heterogeneous clinical presentation. The present study includes seven unrelated Indian adult patients (age range: 20-40 years) having splenomegaly, with or without hepatomegaly, cytopenia and bone abnormality.
\end{abstract}

Methods: The biochemical investigation implicated measuring plasma chitotriosidase enzyme activity followed by confirmatory test of $\beta$-Glucosidase enzyme activity from the leukocytes. The molecular characterization involved patients' initial screening for the common Gaucher mutation (Leu444Pro). Later, all patients were subjected to whole GBA gene coding region study using bidirectional Sanger sequencing. The population screening for common Gaucher disease mutation (Leu444Pro) was executed in 1200 unrelated and healthy Indian subjects by Restriction Fragment Length Polymorphism-Polymerase Chain Reaction technique. The allele frequency was calculated using HardyWeinberg formula.

Results: The biochemical analysis revealed a significant reduction in the $\beta$-Glucosidase activity in all the patients. Also, an elevated level of plasma Chitotriosidase activity in five patients supported their diagnosis of Gaucher disease. Sanger sequencing established four patients with homozygous variation and three patients with compound heterozygous variation in GBA gene. This study uncovers two missense variants (Ala448Thr and Val17Gly) not previously reported in Gaucher disease patients. Also the known mutations like Leu444Pro, Arg329Cys, Asp315Asn, Ser125Arg, and Arg395Cys were identified in these patients. The homology modeling suggested the destabilization of the protein structure due to novel variants. The Leu444Pro mutation screening in the Indian population spotted two people as a carrier. This emerged the carrier frequency of 1:600 along with wild-type allele frequency 0.97113 and mutant allele frequency 0.02887 .

(Continued on next page)

\footnotetext{
* Correspondence: jshethad1@gmail.com

${ }^{1}$ FRIGE's Institute of Human Genetics, FRIGE House, Jodhpur Gam Road,

Satellite, Ahmedabad, Gujarat 380015, India

Full list of author information is available at the end of the article
}

(c) The Author(s). 2018 Open Access This article is distributed under the terms of the Creative Commons Attribution 4.0 International License (http://creativecommons.org/licenses/by/4.0/), which permits unrestricted use, distribution, and reproduction in any medium, provided you give appropriate credit to the original author(s) and the source, provide a link to the Creative Commons license, and indicate if changes were made. The Creative Commons Public Domain Dedication waiver (http://creativecommons.org/publicdomain/zero/1.0/) applies to the data made available in this article, unless otherwise stated. 
(Continued from previous page)

Conclusions: The study reports novel and known variants identified in the GBA gene in seven adult patients. The given study is the first report on the carrier frequency of the Leu444Pro mutant allele in an Indian population which will help understanding the burden and susceptibility of Gaucher disease to affect next generation in India.

Keywords: Adult Gaucher disease, $\beta$-Glucosidase, Chitotriosidase, GBA gene, Glucocerebrosidase, Indian population, Leu444Pro carrier frequency

\section{Background}

Gaucher disease (GD, OMIM\#230800) is a rare autosomal recessive Lysosomal storage disorder (LSDs) which occurs due to an increased accumulation of undegraded glycolipid glucocerebroside in lysosomes [1]. Lysosomes maintain the cells' homeostasis by mediating multiple functions like macromolecules breakdown, phagocytosis, and antigen presentation [2]. Several catabolic enzymes degrade macromolecules in Lysosome and make it available to the cell. A mutation in the genes encoding such Lysosomal enzymes either causes loss of function or decreases the functional expression of these enzymes. Such genetic defect results in substrate accumulate in their respective organs and bloodstreams causing various disorders which are broadly categorized as LSDs [3]. Approximately, LSDs covers 50 rare genetic disorders. Our previous study represents that GD is the most common LSD observed in Indian population [4].

Under normal condition, a lysosomal enzyme $\beta$ glucosidase (EC 3.2.1.45) catabolize glucocerebroside to glucose and ceramide [5]. Glucosylceramidase beta gene (GBA; OMIM*606463), located at the locus 1q22, encodes this enzyme. The loss-of-function mutations in $G B A$ gene prevent the enzyme from cleaving the $\beta$-glucosyl linkage of Glucocerebroside leading to its accumulation in the lysosomes [6]. Macrophages, involved in eliminating leukocytes containing excess glycosphingolipids, are altered in GD. Such lipid burdened macrophages, under light microscopy, looks enlarged due to eccentric nuclei, and condensation of chromatin and cytoplasm [7]. These cells are called 'Gaucher cells' named after Philippe Gaucher who first described it in 1882 in a patient with massive Splenomegaly [8].

Based on the neurological involvement, the GD is classified in three types. Type 1 GD (non-neuronopathic), type 2 GD (acute neuronopathic) and type 3 GD (chronic neuronopathic). Though type $1 \mathrm{GD}$ is heterogenic, the clinical presentations like hepatosplenomegaly, bone disease, and hematological abnormalities like cytopenias are commonly observed [9]. A majority of adult type 1 GD patients are reported in Gaucher registry involving several ethnic groups and races $[10,11]$. Few cases of adult type 1 GD are identified from India $[12,13]$.

Though considered rare, GD is found to be the most common LSD. Its prevalence in general population is estimated to be 1:50000 however, Ashkenazi Jewish population is at higher risk with a prevalence of 1:950 live births $[14,15]$. More than 300 pathogenic mutations have now been identified in GBA gene but the most commonly occurring mutations like c.1226A > G (Asn370Ser), c.1448T>C (Leu444Pro), c.84dupG (84GG), and c.115 + $1 G>A$ (IVS2 + 1G > A) forms approximately $90 \%$ of the total Ashkenazi Jewish GD patients and 50-60\% of the total non-Jewish GD patients $[16,17]$. The mutation c.1448T $>C$ (Leu444Pro) is pan-ethnic. Our earlier study reported that $60.6 \%$ of non-neuronopathic and $3.03 \%$ of sub-acute neuronopathic Indian GD patients reported were identified with c.1448T >C (Leu444Pro) mutation [18].

The given study reports seven patients with Type 1 GD manifested in adulthood along with identification of two novel variants in $G B A$ gene. The study also demonstrates the carrier frequency analysis of the most common GD mutation (Leu444Pro) identified in an Indian population.

\section{Methods \\ Patients}

The present study comprises the patients from clinical cases referred from Institute of Human Genetics after genetic counseling as well as from outside referring physicians. The Ethics committee of the Foundation for Research in Genetics and Endocrinology (FRIGE) at the Institute of Human Genetics approved the study and it was performed in accordance with the tenets of the Declaration of Helsinki. Irrespective of the case reference, a written informed consent for investigation and publication of the data was obtained from the patients or their guardian as per the institutional ethics committee guidelines. The 7 unrelated patients reported, comprises three males and four females in the age range of 20 years to 40 years at the time of investigations. They were referred in the time from 2012 to 2016 with a clinical suspicion of adult GD. The clinical presentation included mild to severe liver/spleen enlargement, anemia, thrombocytopenia and presence of Gaucher cells in bone marrow.

\section{Biochemical investigations}

Six milliliters of blood, drawn from each patient in ethylenediaminetetraacetic acid vacutainer, was subjected to a plasma, leukocyte, and genomic DNA (gDNA) isolation. 


\section{Plasma chitotriosidase screening}

The chitotriosidase enzyme activity was measured in blood plasma using a previously described protocol [19]. In brief, the plasma mixed with 4-MU (4-methylumbeliferryl b-D-N,N,N',N" - triacetylchitotrioside) substrate was incubated at $37{ }^{\circ} \mathrm{C}$. Photo fluorometer with $360 \mathrm{~nm}$ primary and $465 \mathrm{~nm}$ secondary filter measured the fluorescence.

\section{Leukocyte enzyme assay}

Fluorimetric enzyme assay using 4-methylumbelliferyl- $\beta$ $D$-glucopyranoside substrate measured the Lysosomal hydrolase enzyme ( $\beta$-Glucosidase) activity [20].

\section{Molecular genetics investigations DNA extraction and purification}

DNA was isolated from whole blood using the standard salting-out method and quantified using a QIAxpert (Cat. No: 9002340) from Qiagen [21]. The DNA samples were purified using The Genomic DNA Clean \& Concentrator $^{\text {rm }}-25\left(\mathrm{DCC}^{\mathrm{rx}}\right)$ Kit, from Zymo Research, Irvine, California, U.S.A (Cat. No. D4064) and were stored at $20{ }^{\circ} \mathrm{C}$ until investigated.

\section{Primary screening of the common Gaucher mutations (Leu444Pro)}

The DNA samples were amplified in Thermal Cycler-2720 (Applied Biosystems, Inc. India) using our earlier described protocol [18]. The polymerase chain reaction (PCR) product was then subjected to restriction digestion by Restriction endonucleases MspI (New England Biolabs). In brief, $10 \mu \mathrm{l}$ of PCR product was incubated with $0.5 \mu \mathrm{L}$ of $M s p I$ $(10 \mathrm{U} / \mu \mathrm{l})$ at $37{ }^{\circ} \mathrm{C}$ for $3 \mathrm{~h}$. The digested DNA fragments were separated on $2.5 \%$ agarose gel. The above protocol also covers the mutation Arg463Cys which can be distinguished from Leu444Pro on an agarose gel based on the different sizes of the DNA fragments. The codon numbering of the mutations described in this study uses the traditional amino acid residue numbering, which excludes the first 39 amino acids of the leader sequence used in the current nomenclature for $G B A$ mutations.

\section{Single-gene sequencing (GBA gene)}

GBA gene containing 11 exons was amplified using primer sets listed in the Additional file 1. The primers were standardized using nested PCR for specific amplification of the functional gene. For exon 1-2, 35 cycles of amplification; each consisting of initial denaturation $\left(94^{\circ} \mathrm{C}\right.$; $4 \mathrm{~min})$, denaturation $\left(94{ }^{\circ} \mathrm{C} ; 30 \mathrm{~s}\right)$, annealing $\left(65.5{ }^{\circ} \mathrm{C}\right.$; $30 \mathrm{~s})$, elongation $\left(72{ }^{\circ} \mathrm{C} ; 30 \mathrm{~s}\right)$, and final elongation $\left(72{ }^{\circ} \mathrm{C}\right.$; $10 \mathrm{~min}$ ) were run. Amplification for exon 3-4 involved initial denaturation $\left(96{ }^{\circ} \mathrm{C}\right.$; $\left.2 \mathrm{~min}\right)$, denaturation $\left(96{ }^{\circ} \mathrm{C}\right.$; $30 \mathrm{~s})$, annealing $\left(61^{\circ} \mathrm{C} ; 30 \mathrm{~s}\right)$, elongation $\left(74{ }^{\circ} \mathrm{C} ; 60 \mathrm{~s}\right)$, and final elongation $\left(74{ }^{\circ} \mathrm{C}\right.$; $5 \mathrm{~min}$ ) were run. Exon $5-11$ included initial denaturation $\left(96{ }^{\circ} \mathrm{C} ; 2 \mathrm{~min}\right)$ followed by
33 cycles each consisting of denaturation $\left(96^{\circ} \mathrm{C} ; 30 \mathrm{~s}\right)$, annealing $\left(58{ }^{\circ} \mathrm{C}\right.$ to $\left.61{ }^{\circ} \mathrm{C} ; 30 \mathrm{~s}\right)$, elongation $\left(74{ }^{\circ} \mathrm{C} ; 60 \mathrm{~s}\right)$, and final elongation $\left(74{ }^{\circ} \mathrm{C}\right.$; $\left.5 \mathrm{~min}\right)$. PCR products were run on the $2 \%$ agarose gel and visualized under ultraviolet transilluminator.

Sanger sequencing was performed by fluorescent dye-labeled genetic analysis system using capillary electrophoresis technology on the Applied Biosystems ${ }^{\mathrm{TM}}$ SeqStudio $^{\mathrm{rm}}$ Genetic Analyzer with SeqStudio ${ }^{\mathrm{Tm}}$ Data Collection Software. The PCR product, cleaned by Big Dye Terminator v3.1 Clean up, was further processed for cycle sequencing in Thermal Cycler-2720 considering the protocol of initial denaturation $\left(96^{\circ} \mathrm{C} ; 1 \mathrm{~min}\right)$, denaturation $\left(96{ }^{\circ} \mathrm{C} ; 10 \mathrm{~s}\right)$, annealing $\left(50{ }^{\circ} \mathrm{C} ; 5 \mathrm{~s}\right)$, and elongation $\left(60{ }^{\circ} \mathrm{C} ; 4 \mathrm{~min}\right)$. Total 25 cycles were run. The cycle sequencing products (samples) were purified, resuspended in Hi-Di Formamide and transferred to 96 wells plate. The Samples, in a plate covered with septa, were denatured at $95{ }^{\circ} \mathrm{C}$ for $2 \mathrm{~min}$ and snap chilled at $-20{ }^{\circ} \mathrm{C}$ for $2-3 \mathrm{~min}$ before proceeding with the sequencing. The sequences obtained were aligned to the available reference sequence (NM_001005741.2) in The National Center for Biotechnology Information (NCBI) GeneBank database to detect variation.

\section{In silico analysis}

\section{Prediction of the functional effect of the variants}

Six in silico tools identifying the effect of DNA variants (MutationTaster2), coding non-synonymous variants (SIFT), coding and non-coding variants (FATHMM), and amino acid substitution (PolyPhen2, PROVEAN, and MutationAssessor) were employed.

\section{Homology modeling, structure validation and protein stability due to novel variants}

The mutated protein structure of the novel variants was modeled using previously described protocol [22]. In brief, $\beta$-Glucosidase crystallographic structure (PDB ID: 1OGS) was used as the template and the Root Mean Square Deviation (RMSD) of the mutant structures with respect to the wild-type structure was calculated.

\section{Orthologous conservation of the GBA residues harboring the novel variant}

The conservation of the $G B A$ residues incorporating novel variants was checked across species according to the previously described protocol [22]. In brief, the protein sequence of Homo sapiens (NP_001005741) was aligned along with other species using Clastal Omega; an online multiple sequence alignment program. 


\section{Population screening for c.1448T >C (Leu444Pro) variant by RFLP-PCR}

Total 1200 unrelated and healthy population with no history of GD in the family or near relatives were enrolled for the study from different regions of India. The blood samples were collected after an ethics committee approval from the Institute and written informed consent. The DNA was isolated as described previously and was screened for the c.1448T $>C$ (Leu444Pro) variant using previously described RFLP-PCR protocol. The sample size was planned by an online sample size calculator (http://www.raosoft.com/samplesize.html). Allele frequency was calculated through an online HardyWeinberg calculator (http://perinatology.com/calculators/ Hardy-Weinberg.htm). Sanger sequencing, using the aforementioned primers, confirmed the results.

\section{Results}

The patients included in the study presented unexplained hepatomegaly, moderate splenomegaly, anemia, and thrombocytopenia with or without any bone abnormality. Table 1 covers the clinical details and the demographic profile of the patients. Bone marrow aspirates in four cases showed the presence of classical Gaucher cells suggesting the possibility of GD. In addition to the above, patient $\mathrm{P}_{1}$ had difficulty in walking since 15 years of age and his bone X-ray revealed sclerosis and avascular necrosis of the left femur. Patient $\mathrm{P}_{3}$ had undergone splenectomy at the age of 17 years. The pelvis MRI report of the patient $\mathrm{P}_{5}$ revealed hyperintensities over the upper shaft of the right femur along with changes in pelvic floor muscles. Two patients (patient $\mathrm{P}_{5}$ and $\mathrm{P}_{6}$ ) were on imiglucerase Enzyme Replacement Therapy (ERT) before their molecular investigation. None of the patient manifested any neurological involvement. They had an uneventful childhood and the symptoms appeared in early adulthood.

\section{Biochemical analysis}

Five patients $\left(\mathrm{P}_{1}, \mathrm{P}_{2}, \mathrm{P}_{4}, \mathrm{P}_{5}\right.$, and $\left.\mathrm{P}_{7}\right)$ expressed a markedly elevated level of plasma chitotriosidase ranging from 1670 to $72,000 \mathrm{nmol} / \mathrm{h} / \mathrm{ml}$ plasma. Patient $\mathrm{P}_{6}$ presented a normal level of plasma chitotriosidase $(102.4 \mathrm{nmol} / \mathrm{h} / \mathrm{ml}$ plasma) and undetectable chitotriosidase activity was noted in the patient $P_{3}$. $\beta$-Glucosidase enzyme assay from leukocytes revealed a significantly reduced $\beta$-Glucosidase enzyme activity $(\leq 10 \%)$ in all the patients (Table 2 ). This deficient activity confirmed the diagnosis of GD.

\section{Molecular analysis}

The identification of genetic cause of GD in all the patients involved an initial screening for the common

Table 1 Clinical details and demographic profile of the adult patients with type I Gaucher disease

\begin{tabular}{|c|c|c|c|c|c|c|}
\hline Patient ID & $\mathrm{P}_{1}$ & $P_{2}$ & $P_{3}$ & $P_{5}$ & $P_{6}$ & $\mathrm{P}_{7}$ \\
\hline Age at the time of investigation (in years) & 20 & 20 & 26 & 25 & 28 & 40 \\
\hline Sex & M & $\mathrm{F}$ & $\mathrm{F}$ & M & $\mathrm{F}$ & $\mathrm{F}$ \\
\hline Region & GJ & GJ & GJ & PB & UP & $\mathrm{MH}$ \\
\hline \multicolumn{7}{|l|}{ Symptoms } \\
\hline Deep superficial reflexes & & & & & + & \\
\hline Edema (Pelvis) & & & & + & & \\
\hline Heaviness in abdomen & & & & + & & \\
\hline Generalized weakness & & & & & & + \\
\hline Splenomegaly & + & + & + & + & + & + \\
\hline Hepatomegaly & + & & + & + & & \\
\hline \multicolumn{7}{|l|}{ Hematological abnormalities } \\
\hline Anemia & + & + & & & + & + \\
\hline Thrombocytopenia & + & & & + & + & + \\
\hline Cytopenia & + & & & & & \\
\hline Vacuolated lymphocytes & & & & & + & \\
\hline Bone marrow analysis (presence of Gaucher cells) & + & & & + & + & + \\
\hline \multicolumn{7}{|l|}{ Bone abnormalities } \\
\hline Difficulty in walking & + & & & & & \\
\hline Avascular necrosis (left femur) & + & & & & & \\
\hline Enzyme Replacement Therapy & & & & + & + & \\
\hline
\end{tabular}

Abbreviation: F Female, GJ Gujarat, MH Maharashtra, M Male, PB Punjab, UP Uttar Pradesh

Clinical history of the patient $\mathrm{P}_{4}$ is unavailable 
Table 2 Biochemical and molecular analysis of adult patients with type I Gaucher disease

\begin{tabular}{|c|c|c|c|c|c|c|c|c|c|}
\hline \multirow[t]{2}{*}{ Patient ID } & \multicolumn{2}{|c|}{ Biochemical analysis } & \multicolumn{3}{|c|}{ Molecular analysis } & \multicolumn{2}{|c|}{ Allele Frequency } & \multirow{2}{*}{$\begin{array}{l}\text { dbSNP } \\
\text { reference } \\
\text { sequence }\end{array}$} & \multirow[t]{2}{*}{ Reference } \\
\hline & $\begin{array}{c}\text { Plasma } \\
\text { Chitotriosidase } \\
\text { (nmol/hr/ml plasma) }\end{array}$ & $\begin{array}{c}\beta \text {-Glucosidase } \\
(\mathrm{nmol} / \mathrm{hr} / \mathrm{mg} \\
\text { protein) }\end{array}$ & $\begin{array}{l}\text { Variant location } \\
\text { (GBA gene) }\end{array}$ & $\begin{array}{l}\text { Nucleotide change } \\
\text { (Amino Acid change) }\end{array}$ & Zygosity & $\begin{array}{l}1000 \\
\text { Genomes }\end{array}$ & EXAC & & \\
\hline \multirow[t]{2}{*}{$P_{1}$} & $54,503.7$ & $2.5^{\#}$ & Exon 10 & $\begin{array}{l}\text { C.1448T>C } \\
\text { (Leu444Pro) }\end{array}$ & Het & 0.0034 & 0.0031 & rs421016 & [18] \\
\hline & & & Exon 8 & $\begin{array}{l}\text { C.1102C>T } \\
\text { (Arg329Cys) }\end{array}$ & Het & NR & 0.00002472 & rs374306700 & [18] \\
\hline$P_{2}$ & $72,000.0$ & $1.2^{\#}$ & Exon 10 & $\begin{array}{l}\text { c.1459G>A } \\
\text { (Ala448Thr) }\end{array}$ & Hom & NR & NR & rs878853317 & $\begin{array}{l}\text { In this } \\
\text { study }\end{array}$ \\
\hline$P_{3}$ & 0.0 & $1.2^{\#}$ & Exon 10 & $\begin{array}{l}\text { c.1459G>A } \\
\text { (Ala448Thr) }\end{array}$ & Hom & NR & NR & rs878853317 & $\begin{array}{l}\text { In this } \\
\text { study }\end{array}$ \\
\hline $\mathrm{P}_{4}$ & $14,378.0$ & $0.24^{\#}$ & Exon 8 & $\begin{array}{l}\text { c.1060G>A } \\
\text { (Asp315Asn) }\end{array}$ & Hom & NR & 0.000008243 & rs398123526 & {$[24]$} \\
\hline \multirow[t]{2}{*}{$P_{5}$} & 1670.0 & $3.5^{\dagger}$ & Exon 10 & $\begin{array}{l}\text { c.1448T>C } \\
\text { (Leu444Pro) }\end{array}$ & Het & 0.0034 & 0.0031 & rs421016 & [18] \\
\hline & & & Exon 3 & $\begin{array}{l}\text { C.167T>G } \\
\text { (Val17Gly) }\end{array}$ & Het & NR & NR & rs878853318 & $\begin{array}{l}\text { In this } \\
\text { study }\end{array}$ \\
\hline \multirow[t]{2}{*}{$P_{6}$} & 102.4 & $4.65^{\dagger}$ & Exon 10 & $\begin{array}{l}\text { c.1459G>A } \\
\text { (Ala448Thr) }\end{array}$ & Het & NR & NR & rs878853317 & $\begin{array}{l}\text { In this } \\
\text { study }\end{array}$ \\
\hline & & & Exon 5 & $\begin{array}{l}\text { C.492C>G } \\
\text { (Ser125Arg) }\end{array}$ & Het & NR & 0.00003295 & - & {$[24]$} \\
\hline$P_{7}$ & $54,503.7$ & $1.5^{\#}$ & Exon 9 & $\begin{array}{l}\text { C.1300C>T } \\
\text { (Arg395Cys) }\end{array}$ & Hom & NR & NR & - & [18] \\
\hline
\end{tabular}

Abbreviations: The Single Nucleotide Polymorphism database (dbSNP), The Exome Aggregation Consortium (ExAC), Heterozygous (Het), Homozygous (Hom), Not Reported (NR)

Plasma Chitotriosidase normal range: $28.66-62.94 \mathrm{nmol} / \mathrm{hr} / \mathrm{ml}$ plasma

\# $\beta$-Glucosidase enzyme activity done at our center (normal range: $4.0-32.0 \mathrm{nmol} / \mathrm{hr} / \mathrm{mg}$ protein)

${ }^{\dagger} \beta$-Glucosidase enzyme activity done at other centers (normal range: $10.0-45.0 \mathrm{nmol} / \mathrm{hr} / \mathrm{mg}$ protein)

The above variants refers to the GBA gene with transcript ID ENST00000327247.5 and reference sequence number NM_001005741.2

mutations (Leu444Pro) observed in GD [18, 23]. Patient $\mathrm{P}_{1}$ and $\mathrm{P}_{5}$ were found to carry a heterozygous copy of c.1448T >C (Leu444Pro) variant in exon 10 of GBA gene. As a single variant or no variant was detected in the initial screening, the further investigation involved the sequencing of the complete coding region of GBA gene in all the patients. Sanger sequencing identified four patients $\left(\mathrm{P}_{2}, \mathrm{P}_{3}, \mathrm{P}_{4}\right.$, and $\left.\mathrm{P}_{7}\right)$ with a homozygous variation and three patients $\left(\mathrm{P}_{1}, \mathrm{P}_{5}\right.$, and $\left.\mathrm{P}_{6}\right)$ with compound heterozygous variation in $G B A$ gene. Figure 1 depicts an illustrative representation of the location of the variants identified through Sanger Sequencing.

The variants identified as compound heterozygous in the patient $P_{1}$ are known pathogenic variants and have also been identified in our previously published data [18]. The patients $P_{2}$ and $P_{3}$ harbor a homozygous copy of a variant c.1459G>A (Ala448Thr) in exon 10 (Table 2). This mutant allele is not reported in the 1000 Genomes database or The Exome Aggregation Consortium (ExAC). To the best of our knowledge, this variant has not been previously reported in the patients with GD. The patient $\mathrm{P}_{4}$ carried a known variant; previously reported in GD [24]. The patient $P_{5}$ involved a c.167T $>G$ (Val17Gly) variant along with known p.Leu444Pro variant in a compound heterozygous form. The variant p.Val17Gly is not reported in either 1000 Genomes or ExAC databases. Also, the variant has not been previously established with GD.

Patient $\mathrm{P}_{6}$ was identified as compound heterozygous with a variant Ala448Thr (as identified in the patient $\mathrm{P}_{2}$ and $\mathrm{P}_{3}$ ) and another known reported variant Ser125Arg [24]. The patient $\mathrm{P}_{7}$ harbors a known variant previously reported by us [18].

The in silico tools described above established the functional effects of the variants identified [see Additional file 2]. The novel variants (Ala448Thr and Val17Gly) were found to be disease-causing. Protein homology modeling further established the severe damaging effect of these novel variants. The variation occurred at highly evolutionarily conserved and functionally active residual domain in the protein leading to conformational changes or destabilization of the protein structure as shown in Fig. 2. The RMSD values for the modeled mutants were significant for the pathogenicity of the novel variants $(0.147$ for p.Ala448Thr and 0.144 for p.Val17Gly) compared to $\sim 0.6$ Å RMSD for wild type protein structure [25].

\section{Population screening for c.1448T >C (Leu444Pro) common mutation}

The study included 17 subjects from the Eastern zone, 740 subjects from the Western zone, 114 subject from 


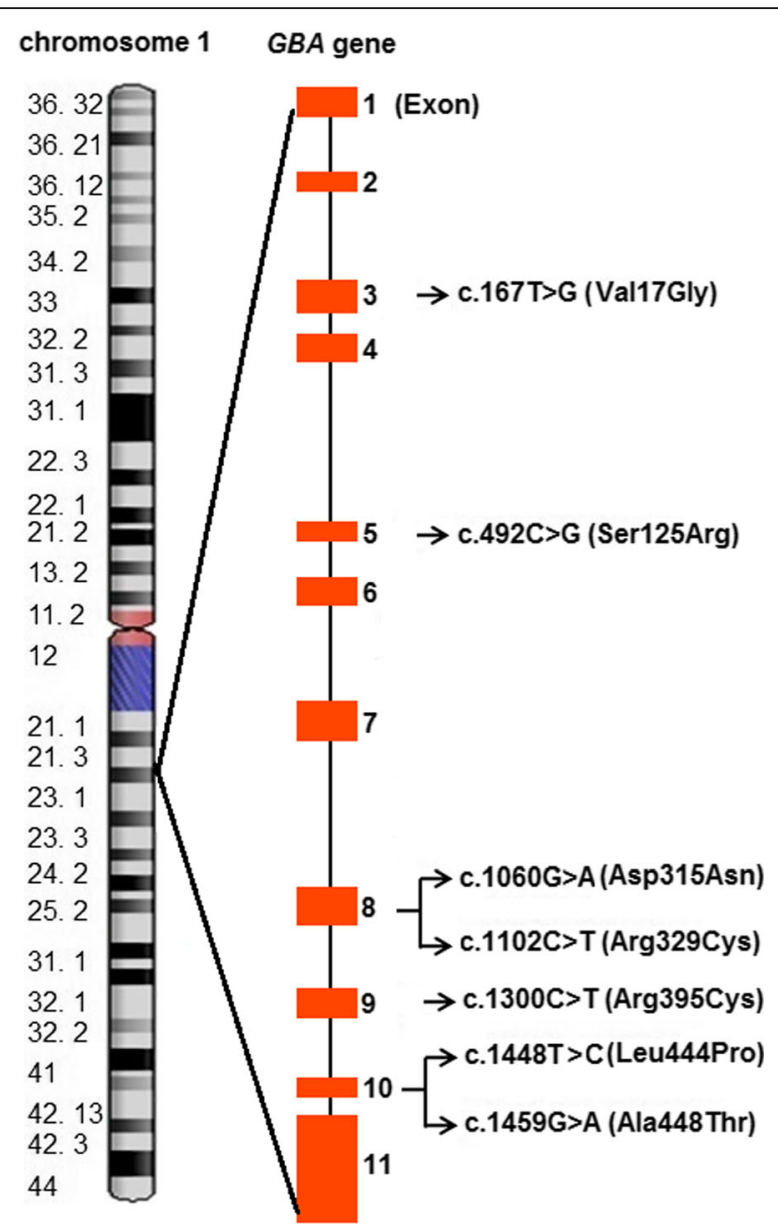

Fig. 1 Illustrative representation of the distributions of the variants identified in Indian adult Gaucher patients investigated in this study. Variations in exon 3, 5, 8, 9, and 10 of GBA gene were observed

the Northern zone, 165 subjects from the Southern zone, and 164 subjects from the central zone of India. The sample size of 1200 subjects yielded a 3.6\% margin of error with a confidence limit of 99\%. From 1200 subjects screened, 2 subjects exhibited a carrier status for c.1448T>C (Leu444Pro) as identified on the agarose gel. Sanger sequencing confirmed their heterozygosity [see Additional file 3]. This has yielded the carrier frequency of 1:600 for the p.Leu444Pro variant in GBA gene. Using the Hardy-Weinberg formula, the allele frequency of wild-type allele (T) is found to be 0.97113 and that of a mutant allele $(\mathrm{C})$ is 0.02887 (Table 3 ).

\section{Discussion}

Patients enrolled in this study exhibited clinical presentations like splenomegaly in all, with visceral infiltration (pancytopenia), and bone manifestations in some of them. Bone marrow examination in the majority of the patients showed classical Gaucher cells. Gaucher cells mainly infiltrate liver, spleen, bone marrow and lungs.
All the patients in our study manifested unexplained splenomegaly, which is most commonly observed in type $1 \mathrm{GD}$ with its prevalence in more than $90 \%$ of cases; however, hepatomegaly is less frequent with its estimate observation in $60-80 \%$ patients [14].

Bone marrow aspirates show the presence of Gaucher cells which are lipid encroached macrophages. Activated macrophages produced a chitotriosidase enzyme (EC 3.2.1.14) which makes it an apt diagnostic biomarker for the evaluation of GD patients [26]. The present study showed markedly elevated levels of plasma chitotriosidase enzyme activity in five out of seven patients $(\sim 71 \%)$. However, low or undetectable chitotriosidase enzyme activity in another two patients might possibly due to the presence of a null allele in Chitinase 1 (CHIT1) gene [27]. The comparatively low chitotriosidase activity in patients $\mathrm{P}_{5}$ and $\mathrm{P}_{6}$ might also be attributable to the enzymatic replacement therapy. A study by Hollak et al. reported a dramatic decrease in the chitotriosidase activity in the patients subjected to enzyme supplementation therapy [28].

Three mutations Arg329Cys, Arg395Cys, and Ser125Arg identified in the patients are known to be localized in Domain II/TIM Barrel which contains the catalytic active site of the protein and hence affects the catalytic function by producing mild to severe phenotype [29]. This may justify the occurrence of heterogeneous phenotype in these patients (from hepatosplenomegaly, thrombocytopenia to presence or absence of bone involvement).

Moreover, two novel mutations (Ala448Thr and Val17Gly) have been detected in the present series without any bone involvement. The in silico protein modeling analysis has demonstrated that mutant allele Ala448Thr is located in Ig like domain (domain II) at a significant distance from the active site and alters folding of this domain hence disrupting the hydrophobic core. Another allele Val17Gly is located in domain I of the GBA molecule which leads to misfolding of the protein due to alteration in the $\beta$-sheet.

One of the patients in the present study harbors a compound heterozygous mutation (Leu444Pro/ Arg329Cys) along with a phenotype of avascular necrosis as the primary sign with mild hepatosplenomegaly while another patient with Leu444Pro/Ser125Arg mutation present with thrombocytopenia and splenomegaly. Very few adult patients are reported as compound heterozygous for Leu444Pro and second rare allele (Leu444Pro/rare allele) $[10,11,30]$. Ito et al., 2013 reported a compound heterozygous mutation Leu444Pro/Asp409His in a 21-year-old adult male with GD associated with temporal intestinal hemorrhage [31]. The gene conversion and crossing over events between $G B A$ gene and its highly homologous pseudogene (psGBA) produces mutated complex alleles, which are frequently, associated with the mutations Asn370Ser and Leu444Pro. A study by Saleem 


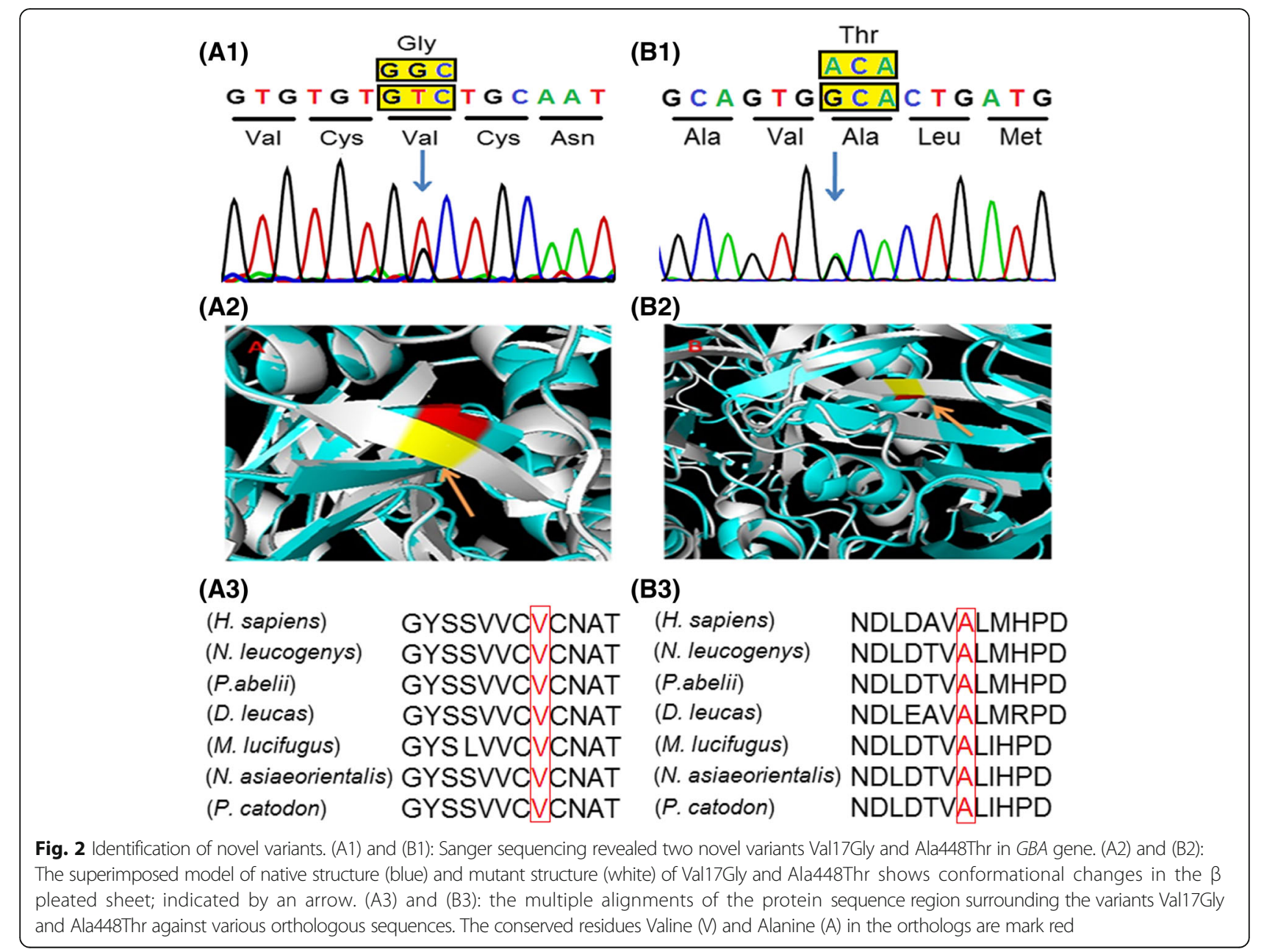

Table 3 Carrier frequency analysis of Gaucher disease common mutation C.1448T>C (Leu444Pro)

\begin{tabular}{ll}
\hline Disease & Gaucher \\
Gene & GBA \\
Mutation & C.1448T>C \\
Samples tested & 1200 \\
Heterozygote detected in this study & T/C: 2 \\
Carrier frequency & $1: 600$ \\
allele frequency & (T>C) 1:1200 \\
Wild-type allele frequency & T: 0.97113 \\
Mutant allele frequency & C: 0.02887 \\
Transcript identification & ENST00000327247.5 \\
Mutation type & Missense \\
Mutation effect & Glucocerebrosidase enzyme \\
Promising therapeutic approaches & Enzyme Replacement Therapy (ERT) \\
\hline
\end{tabular}

et al. reported four Egyptian type 1 GD patients with compound heterozygous Asn370Ser/RecNciI [32]. A study by Lee et al. reported a case of Indonesian Chinese boy harboring compound heterozygous Leu444Pro/RecNclil [33]. Similar study in Ukrainian patients, by Olkhovych et al., revealed four patients of type I GD with compound heterozygous Leu444Pro and complex mutants [34]. Though Asn370Ser is not seen in Indian population, our recent unpublished work on 100 GD children has observed Leu444Pro with complex allele. Few studies have demonstrated a strong link between late-onset Parkinson disease (LOPD) and presence of the Leu444Pro allele [35, 36]. This warrants the follow-up of our patients for LOPD. In addition to this, type $1 \mathrm{GD}$ and/or adult GD is also found to be associated with myoclonic epilepsy, malignant bone tumor, synucleinopathies including Parkinson's disease and dementia with Lewy bodies [37-40].

Endogamous marriage practice in India has increased the burden of several autosomal recessive diseases within each specific community. The cost of therapeutic approaches like ERT, small molecular chaperones, and low success with Stem Cell Transplantation limits their 
availability to wide population [41]. Therefore, the only means of preventing the occurrence of these diseases is either by prenatal diagnosis or pre-marriage counseling. Our earlier studies have identified GD as the most common storage disorder with Leu444Pro as the most common mutant allele in an Indian population [4, 18]. A study by Kadali et al. also established a higher incidence of GD in India [26]. The present study identified 2 unrelated subjects with no family history of GD to be heterozygous for c.1448T $>$ C (Leu444Pro) mutation suggesting the carrier frequency to be 1:600. Considering a heterogeneous population in India with various social, regional and community-based marriage practices, it is very expected that certain area in the country is likely to have higher incidences of GD where consanguineous marriage practice is common. Our previous study revealed that regions of Maharashtra have a higher rate of GD as compared to other parts of the country [4].

\section{Conclusions}

The given study reports seven patients with an adult onset of type $1 \mathrm{GD}$ with all mutations clustered in exon 8 and 10. Also, the study contributes two novel variants to the spectrum of $G B A$ gene mutations along with providing knowledge about the prevalence of most common GBA gene mutation c.1448T>C (Leu444Pro) mutation in a general Indian population. This can help in maintaining population health quotient by doing pre-marital counseling, especially in endogamy community and hence minimizing the disease burden amongst the population. In view of milder clinical manifestation in the course of adult GD, differential diagnosis of GD needs to be suspected in patients with unexplained anemia, pancytopenia and/or hepato/splenomegaly.

\section{Additional files}

Additional file 1: List of primers used for GBA gene sequencing. The exons and the exon-intron boundaries of the GBA gene were bidirectionally sequenced using the given set of primers. (DOC $30 \mathrm{~kb}$ )

Additional file 2: In silico analysis of the functional effect of the variants identified in the adult patients with type $1 \mathrm{GD}$. The in silico tools predicting the effect of DNA variants, coding non-synonymous variants, amino acid substitution, and non-coding variants were employed to predict the functional effect of the variants identified in the given study. (DOC $37 \mathrm{~kb}$ )

Additional file 3: Population screening of the c.1448T>C (Leu444Pro) variant. The screening identified two carriers of Leu444Pro out of 1200 population. This gives the carrier frequency of 1:600. Sanger sequencing confirmed the results. (DOC $236 \mathrm{~kb}$ )

Additional file 4: ClinVar Accession ID of the variants generated in the given study. The variants identified through Sanger sequencing are reported in NCBI ClinVar database. The file provides accession ID and the links to an individual variant. (DOC $29 \mathrm{~kb}$ )

\section{Abbreviations}

CHIT1: Chitinase 1; ERT: Enzyme Replacement Therapy; ExAC: The Exome Aggregation Consortium; FATHMM: Functional Analysis Through Hidden
Markov Models; GBA: Glucosylceramidase beta gene; GD: Gaucher disease; LOPD: Late-onset Parkinson disease; NCBI: The National Center for Biotechnology Information; PolyPhen2: Polymorphism Phenotyping v2; PROVEAN: Protein Variation Effect Analyzer; RMSD: Root Mean Square Deviation; SIFT: Scale-invariant feature transform

\section{Acknowledgements}

We show our gratitude to the patients for their support and without their consent this study would not have been possible.

\section{Funding}

This work is partially supported by the Department of Health Research/ Indian Council of Medical Research [grant no.: GIA/31(ii)/2014-DHR] and Department of Biotechnology [BT/PR4112/MED/12/654/2014], Government of India. The funding agency was not directly or indirectly involved in the study design, specimen collection, analysis, interpretation of the data, and preparation of the manuscript.

\section{Availability of data and materials}

The dataset generated and/or analyzed during the current study is available in the ClinVar repository [see Additional file 4].

\section{Authors' contributions}

Conceived and designed the experiments: JS and FS. Clinical analysis: JS, RP, and SP. Carrier frequency analysis: DP, CA, and RB. Sanger sequencing: MM, PN. Data analysis: DP and MM. Manuscript writing (revised draft): DP. Critical revisions and approval of final manuscript: JS and FS. All authors reviewed and approved the final manuscript.

\section{Ethics approval and consent to participate}

The given study has been approved by the institutional ethics committee [FRIGE's Institute of Human Genetics] with approval number FRIGE/IEC/14/ 2016 dated 19th November 2016. This process is in accordance with the declaration of Helsinki. An informed consent for investigation and publication of their clinical details and/or clinical images was obtained from the patient or an accompanying guardian at the time of enrollment for the study [This was in accordance with the requirement of the institutional ethics committee].

\section{Consent for publication}

Informed written consent was obtained from all the participants or the accompanying guardian for publication of the participants' clinical details and/or clinical images. A copy of the written consent is available for review by the editor of this journal.

\section{Competing interests}

The authors declare that they have no competing interests (financial or nonfinancial) in the present study.

\section{Publisher's Note}

Springer Nature remains neutral with regard to jurisdictional claims in published maps and institutional affiliations.

\section{Author details}

${ }^{1}$ FRIGE's Institute of Human Genetics, FRIGE House, Jodhpur Gam Road, Satellite, Ahmedabad, Gujarat 380015, India. ${ }^{2}$ Center of Medical Genetics, Sir Ganga Ram Hospital, Rajinder Nagar, New Delhi 110060, India. ${ }^{3}$ Sanjay Gandhi Post Graduate Institute of Medical Science, Lucknow, Uttar Pradesh 226014, India.

Received: 16 July 2018 Accepted: 12 September 2018

Published online: 01 October 2018

\section{References}

1. Beutler E, Grabowski GA. Gaucher disease. In: Scriver CR, Beaudet AL, Sly WS, Valle $D$, editors. The metabolic and molecular bases of inherited disease. New York: McGraw-Hill; 2001. p. 3635-68.

2. Boustany RM. Lysosomal storage diseases-the horizon expands. Nat Rev Neurol. 2013;9(10):583-98.

3. Platt FM, Boland B, van der Spoel AC. The cell biology of disease: Iysosomal storage disorders: the cellular impact of lysosomal dysfunction. J Cell Biol 2012;199(5):723-734. 
4. Sheth J, Mistri M, Sheth F, Shah R, Bavdekar A, Godbole K, et al. Burden of lysosomal storage disorders in India: experience of 387 affected children from a single diagnostic facility. JIMD Rep. 2014;12:51-63.

5. Ayto R, Hughes DA. Gaucher disease, and myeloma. Crit Rev Oncog. 2013; 18(3):247-68.

6. Brady RO, Kanfer J, Shapiro D. The metabolism of glucocerebrosides. I. Purification and properties of a glucocerebroside-cleaving enzyme from spleen tissue. J Biol Chem. 1965;240:39-43.

7. Stirnemann J, Belmatoug N, Camou F, Serratrice C, Froissart R, Caillaud C, et al. A review of Gaucher disease pathophysiology, clinical presentation and treatments. Int J Mol Sci. 2017;18(2):441.

8. Gaucher P.C.E. De l'epithelioma primitif de la rate, hypertrophie idiopathique de la rate sans leucemie. Faculte de Medecine, These de Paris, 1882;31.

9. Thomas AS, Mehta A, Hughes DA. Gaucher disease: haematological presentations and complications. Br J Haematol. 2014;165(4):427-40.

10. Charrow J, Andersson HC, Kaplan P, Kolodny EH, Mistry P, Pastores G, et al. The Gaucher registry: demographics and disease characteristics of 1698 patients with Gaucher disease. Arch Intern Med. 2000;160(18):2835-43.

11. Fairley C, Zimran A, Phillips M, Cizmarik M, Yee J, Weinreb N, et al. Phenotypic heterogeneity of N370S homozygotes with type I Gaucher disease: an analysis of 798 patients from the ICGG Gaucher registry. J Inherit Metab Dis. 2008;31(6): 738-44.

12. Jain W, Yelwatkar S. Unusual presentation of adult Gaucher's disease: a long and difficult road to diagnosis. Indian J Endocrinol Metab. 2011; 15(3):224-6.

13. Nemani S, Agrawal B, Danda S, George B. Gaucher disease presenting in an adult with intracerebral bleed. J Assoc Physicians India. 2017;65(4):89-90

14. Stirnemann J, Vigan M, Hamroun D, Heraoui D, Rossi-Semerano L, Berger MG, et al. The French Gaucher's disease registry: clinical characteristics, complications and treatment of 562 patients. Orphanet J Rare Dis. 2012;7:77.

15. Ron I, Horowitz M. ER retention and degradation as the molecular basis underlying Gaucher disease heterogeneity. Hum Mol Genet. 2005;14:2387-98.

16. Hruska KS, LaMarca ME, Scott CR, Sidransky E. Gaucher disease: mutation and polymorphism spectrum in the glucocerebrosidase gene (GBA). Hum Mutat. 2008;29:567-83.

17. Pastores GM, Hughes DA. Gaucher Disease. 2018. https://www.ncbi.nlm.nih. gov/books/NBK1269/. Assessed 25 Jun 2018.

18. Ankleshwaria C, Mistri M, Bavdekar A, Muranjan M, Dave U, Tamhankar P, et al. Novel mutations in the glucocerebrosidase gene of Indian patients with Gaucher disease. J Hum Genet. 2014;59(4):223-8.

19. Sheth JJ, Sheth FJ, Oza NJ, Gambhir PS, Dave UP, Shah RC. Plasma chitotriosidase activity in children with lysosomal storage disorders. Indian J Pediatr. 2010;77(2): 203-5.

20. Shapria E, Blitzer MG, Miller JB, et al. Fluorometric assays in biochemical genetics: a laboratory manual: Oxford University press; 1989.

21. Miller SA, Dykes DD, Polesky HF. A simple salting out procedure for extracting DNA from human nucleated cells. Nucleic Acids Res. 1988;16(3):1215.

22. Sheth J, Bhavsar R, Gandhi A, Sheth F, Pancholi D. A case of Raine syndrome presenting with facial dysmorphy and review of literature. BMC Med Genet. 2018;19(1):76.

23. Muranjan M. Gaucher Disease. In: Gupta P, Menon PS, Ramji S, Lodha R, editors. PG textbook of pediatrics. New Delhi: Jaypee Brothers Medical Publishers (P) Ltd; 2015. p. 109-18.

24. Rolfs A, Oprea G, Kramp G, Giese AK, Zielke S, Lukas J, et al. Glucosylsphingosine concentration in the blood of Gaucher patients reflects the severity of GBA mutations. Mol Genet Metab. 2017. https://doi.org/10.1016/j.ymgme.2016.11.299.

25. Lieberman RL. A guided tour of the structural biology of Gaucher disease: acid- $\beta$-glucosidase and Saposin C. Enzyme Res. 2011;2011:97323.

26. Kadali S, Kolusu A, Sunkara S, Gummadi MR, Undamatla J. Clinical evaluation of chitotriosidase enzyme activity in Gaucher and Niemann pick a/B diseases: a retrospective study from India. Clin Chim Acta. 2016;457:8-11.

27. Grace ME, Balwani M, Nazarenko I, Prakash-Cheng A, Desnick RJ. Type 1 Gaucher disease: null and hypomorphic novel chitotriosidase mutationsimplications for diagnosis and therapeutic monitoring. Hum Mutat. 2007; 28(9):866-73.

28. Hollak CE, van Weely S, van Oers MH, Aerts JM. Marked elevation of plasma chitotriosidase activity. A novel hallmark of Gaucher disease. J Clin Invest. 1994;93(3):1288-92.

29. Malini E, Grossi S, Deganuto M, Rosano C, Parini R, Dominisini S, et al. Functional analysis of 11 novel GBA alleles. Eur J Hum Genet. 2014; 22(4):511-6.
30. Hatton CE, Cooper A, Whitehouse C, Wraith JE. Mutation analysis in 46 British and Irish patients with Gaucher's disease. Arch Dis Child. 1997;77(1):17-22.

31. Ito J, Saito T, Numakura C, Iwaba A, Sugahara S, Ishii R, et al. A case of adult type 1 Gaucher disease complicated by temporal intestinal hemorrhage. Case Rep Gastroenterol. 2013;7(2):340-6.

32. Saleem TH, Hassan MH, El-AbdAhmed A, Sayed AA, Mohamed NA, Elsayh KI, et al. Clinical and genetic assessment of pediatric patients with Gaucher's disease in upper Egypt. EJMHG. 2017;18(3):249-55.

33. Lee YS, Poh LK, Ida H, Loke KY. Type II Gaucher disease: compound heterozygote with RecNcil and L444P mutations. J Trop Pediatr. 2001;47(2):115-7.

34. Olkhovych NV, Nedoboy AM, Pichkur NO, Gorovenko NH. Analysis of mutations in GBA gene in Ukrainian patients with Gaucher disease. Biopolym Cell. 2017; 33(1):34-47.

35. Aharon-Peretz J, Rosenbaum H, Gershoni-Baruch R. Mutations in the glucocerebrosidase gene and Parkinson's disease in Ashkenazi Jews. N Engl J Med. 2004;351(19):1972-7.

36. Wang Y, Liu L, Xiong J, Zhang X, Chen Z, Yu L, et al. Glucocerebrosidase L444P mutation confers genetic risk for Parkinson's disease in Central China. Behav Brain Funct. 2012;8:57.

37. Park JK, Orvisky E, Tayebi N, Kaneski C, Lamarca ME, Stubblefield BK, et al. Myoclonic epilepsy in Gaucher disease: genotype-phenotype insights from a rare patient subgroup. Pediatr Res. 2003:53(3):387-95.

38. Böhm P, Kunz W, Horny HP, Einsele H. Adult Gaucher disease in association with primary malignant bone tumors. Cancer. 2001;91(3):457-62.

39. Sidransky E, Nalls MA, Aasly JO, Aharon-Peretz J, Annesi G, Barbosa ER, et al. Multicenter analysis of glucocerebrosidase mutations in Parkinson's disease. N Engl J Med. 2009;361(17):1651-61.

40. Nalls MA, Duran R, Lopez G, Kurzawa-Akanbi M, McKeith IG, Chinnery PF, et al. A multicenter study of glucocerebrosidase mutations in dementia with Lewy bodies. JAMA Neurol. 2013;70(6):727-35.

41. Abdelwahab M, Blankenship D, Schiffmann R. Long-term follow-up and sudden unexpected death in Gaucher disease type 3 in Egypt. Neurol Genet. 2016:2:1-5.

Ready to submit your research? Choose BMC and benefit from:

- fast, convenient online submission

- thorough peer review by experienced researchers in your field

- rapid publication on acceptance

- support for research data, including large and complex data types

- gold Open Access which fosters wider collaboration and increased citations

- maximum visibility for your research: over $100 \mathrm{M}$ website views per year

At $\mathrm{BMC}$, research is always in progress.

Learn more biomedcentral.com/submissions 